University of Nebraska - Lincoln

DigitalCommons@University of Nebraska - Lincoln

Agronomy \& Horticulture -- Faculty Publications

Agronomy and Horticulture Department

1999

\title{
Loci Controlling Resistance to High Plains Virus and Wheat Streak Mosaic Virus in a B73 $\times$ Mo17 Population of Maize
}

\author{
A. Marçon \\ University of Nebraska - Lincoln
}

S. M. Kaeppler

University of Wisconsin, smkaeppl@facstaff.wisc.edu

S. G. Jensen

USDA, Agricultural Research Service

\author{
L. Senior \\ Novartis Seeds, Inc. \\ C. Stuber \\ North Carolina State University
}

Follow this and additional works at: https://digitalcommons.unl.edu/agronomyfacpub

Part of the Agricultural Science Commons, Agriculture Commons, Agronomy and Crop Sciences Commons, Botany Commons, Horticulture Commons, Other Plant Sciences Commons, and the Plant Biology Commons

Marçon, A.; Kaeppler, S. M.; Jensen, S. G.; Senior, L.; and Stuber, C., "Loci Controlling Resistance to High Plains Virus and Wheat Streak Mosaic Virus in a B73 × Mo17 Population of Maize" (1999). Agronomy \& Horticulture -- Faculty Publications. 1326.

https://digitalcommons.unl.edu/agronomyfacpub/1326

This Article is brought to you for free and open access by the Agronomy and Horticulture Department at DigitalCommons@University of Nebraska - Lincoln. It has been accepted for inclusion in Agronomy \& Horticulture -Faculty Publications by an authorized administrator of DigitalCommons@University of Nebraska - Lincoln. 


\title{
CELL BIOLOGY \& MOLECULAR GENETICS
}

\section{Loci Controlling Resistance to High Plains Virus and Wheat Streak Mosaic Virus in a B73 $\times$ Mo17 Population of Maize}

\author{
A. Marçon, S. M. Kaeppler,* S. G. Jensen, L. Senior, and C. Stuber
}

\begin{abstract}
High Plains disease has the potential to cause significant yield loss in susceptible corn (Zea mays L.) and wheat (Triticum aestivum L.) genotypes, especially in the central and western USA. The primary causal agent, High Plains virus (HPV), is vectored by wheat curl mite (WCM; Aceria tossichella Keifer), which is also the vector of wheat streak mosaic virus (WSMV). In general, the two diseases occur together as a mixed infection in the field. The objective of this research was to characterize the inheritance of HPV and WSMV resistance using $B 73$ (resistant to HPV and WSMV) $\times$ Mo17 (moderately susceptible to HPV and WSMV) recombinant inbred lines. A population of 129 recombinant inbred lines scored for 167 molecular markers was used to evaluate resistance to WSMV and to a mixed infection of WSMV and HPV. Loci conferring resistance to systemic movement of WSMV in plants mapped to chromosomes 3,6 , and 10, consistent with the map position of wsm2, wsm1, and wsm.3, respectively. Major genes for resistance to systemic spread of HPV in doubly infected plants mapped to chromosomes 3 and 6 , coincident or tightly linked with the WSMV resistance loci. Analysis of doubly infected plants revealed that chromosome 6 had a major effect on HPV resistance, consistent with our previous analysis of $B 73 \times W 64 A$ and $B 73 \times$ Wf9 populations. Quantitative trait loci (QTL) affecting resistance to localized symptom development mapped to chromosomes 4 (umc66), 5 (bnl5.40), and 6 (umc85), and accounted for $24 \%$ of the phenotypic variation. Localized symptoms may reflect the amount of mite feeding or the extent of virus spread at the point of infection. Identification of cosegregating markers may facilitate selection for HPV and WSMV resistance in corn breeding programs.
\end{abstract}

$\mathrm{H}$ IgH Plains disease in susceptible wheat and maize genotypes has the potential to cause serious economic losses (Jardine et al., 1994; Jensen and Lane, 1994; Jensen et al., 1996). The primary causal agent of the disease, HPV (Jensen and Lane, 1994; Ahn, et al., 1996), is vectored by WCM, which is also the vector of WSMV. In general, the two diseases occur together as a mixed infection in the field (Jensen, 1994).

Symptoms in maize include severe stunting and general chlorosis mixed with mosaic, flecking, or streaking.

A. Marçon, Dep. of Agronomy, University of Nebraska, Lincoln, NE 68583-0915; S.M. Kaeppler, Dep. of Agronomy, University of Wisconsin, Madison, WI 53706-1597; and S.G. Jensen, USDA-ARS, Wheat, Sorghum, and Forage Research Unit, Lincoln, NE, 685830722; L. Senior, Novartis Seeds, Inc., 3054 Cornwallis Rd., Research Triangle Park, NC 27709; C. Stuber, Dep. of Genetics, North Carolina State Univ., Raleigh, NC 27695-7614. Work supported in part from CAPES, from the University of Nebraska-Lincoln, Center for Biotechnology, Lincoln, NE, and by Pioneer Hi-Bred, International, Inc. Received 21 Sept. 1998. *Corresponding author (smkaeppl@facstaff. wisc.edu).

Published in Crop Sci. 39:1171-1177 (1999).
The appearance of reddish purple streaks, initiating at leaf margins and leaf tips and leading to a reddening of the leaves, is genotype-dependent (Marçon et al., 1996, 1997a). Light-green circular spots can also be a characteristic of the disease symptom development in certain genotypes. Many variables have been reported to influence host response to infection, including genotype, time of infection, and time of the year. In general, susceptible maize plants infected as seedlings show the most severe symptom development.

We have previously characterized symptom development on 30 maize inbred lines doubly infected with both HPV and WSMV by WCM inoculation (Marçon et al., 1997a). Inbred lines were variable in symptom development at the point of mite feeding (localized symptom development) as well as in the rate and extent of systemic HPV and WSMV movement (systemic symptom development). Our observations of these same genotypes in the field indicate that resistance to systemic virus spread is the trait of most importance for fieldgrown plants (Jensen, Marçon, Kaeppler, 1994, unpublished data). Most genotypes susceptible to systemic spread of HPV were also susceptible to systemic spread of WSMV as determined by enzyme-linked immunosorbent assay (ELISA) analysis of virus titer in doubly infected plants. An exception to this observation was N194, an inbred line susceptible to systemic spread of HPV but not WSMV. The devastating effect of HPV was very evident in this study. Plants mechanically infected with WSMV alone showed typical symptoms but grew nearly as vigorously as uninoculated controls; the same susceptible genotypes doubly infected with HPV and WSMV were very stunted, sometimes dying within a few weeks of infection.

Genetic analysis of segregating populations of B73 $\times$ W64A and B73 $\times$ Wf9 provided an explanation for the correlation of HPV and WSMV systemic movement (Marçon et al., 1997b). The $F_{2}$ plants WCM-inoculated with both HPV and WSMV showed a cosegregation of resistance to systemic spread of the two pathogens. Molecular markers tightly linked to wsml on chromosome 6S cosegregated with symptom development, and near-isogenic lines selected for allelic divergence at the $6 \mathrm{~S}$ region also showed cosegregation of the phenotypes.

Abbreviations: DAS-ELISA, double antibody sandwich-enzymelinked immunosorbent assay; ELISA, enzyme-linked immunosorbent assay; $(\mathrm{H})$, hand inoculated; HPV, high plains virus; $\mathrm{kDa}$, kilodalton; (M), mite inoculated; QTL, quantitative trait loci; RI, recombinant inbred; SSR, simple sequence repeat; WCM, wheat curl mite; WSMV, wheat streak mosaic virus. 
This study did not allow determination of linkage vs. pleiotropy for the two virus resistance phenotypes, and characterized HPV resistance may be a reaction specific to the HPV-WSMV coinfection complex.

The objective of this study was to characterize the inheritance of resistance to HPV and WSMV using B73 $\times$ Mo17 recombinant inbred lines. Mo17 is a moderately susceptible genotype and is not related by pedigree to the previously analyzed Wf9. Transgressive segregation in a B73 $\times$ Mo17 recombinant inbred population indicated oligogenic inheritance and therefore suggested that additional genes for resistance would be found. In addition, the use of inbred lines allowed a better comparison of these genotypes when infected with WSMV alone or when doubly infected with HPV and WSMV than the $F_{2}$ population in our previous study (Marcon et al., 1997). We have continued to use double infection of WSMV and HPV by mite inoculation because (i) we have not successfully isolated a pure culture of HPV or identified a procedure to inoculate many genotypes efficiently with HPV alone, and (ii) mite inoculation with both pathogens best approximates the challenge experienced by plants grown in the field.

\section{MATERIALS AND METHODS}

\section{Plant and Virus Description}

We evaluated $174 \mathrm{~B} 73 \times$ Mo17 recombinant inbreds for their reaction to HPV and WSMV. Seed of recombinant inbred families and marker data were obtained from Pioneer Hi-Bred International (45 lines) and from C. Stuber (129 lines), North Carolina State University, USDA-ARS. The North Carolina State University poplation was used in the model-building phase of the analysis and the Pioneer Hi-Bred population was used to confirm the models. Data from the two populations were not combined because only a small proportion of the molecular markers were in common.

The isolate of HPV, obtained during the spring of 1994 , was designated as High Plains virus-Texas (HPV-TX). This isolate was used for all greenhouse mite-inoculation experiments in this and previous experiments (Marçon et al., 1997a, 1998). The mite colony used to inoculate plants transmitted a mixed infection of HPV and WSMV. The strain of WSMV in this colony is designated WSMV-AM and was isolated by mechanical inoculation of A556, a WSMV-susceptible maize genotype, with sap from mite-inoculated maize plants. Since HPV is not transmissible by the finger-thumb rub inoculation procedure, this mechanical inoculation resulted in a pure culture of WSMV-AM, which has been maintained on susceptible maize genotypes as a source of inoculum for WSMV testing. Finger-thumb rub inoculation (McKinney, 1949) with WSMV allows comparison of doubly infected plants with plants infected by WSMV alone. The viruliferous mite colony carrying the disease complex was maintained in growth chambers containing HPV and WSMV on susceptible wheat plants ("Centurk') under conditions of $25^{\circ} \mathrm{C}, 16$-h photoperiod, and $\approx 70 \%$ humidity. Maize susceptible checks including W64A and Wf9, and parents B73 and Mo17 were included in all experiments.

\section{Plant Inoculation Procedure}

Fifteen kernels of each $\mathrm{B} 73 \times \mathrm{Mo} 17$ recombinant inbred (RI) population were sown in three 15 -cm-diameter pots containing sterilized soil in the greenhouse with five seeds planted per pot. Lines were evaluated in two separate experiments.
Population 1 consisted of 129 lines, and Population 2 consisted of 45 lines. Each experiment consisted of three pots of five seeds per genotype. Plants in one pot were WCM-infected with both viruses, plants in a second pot finger-thumb rub inoculated with WSMV, and plants in the third pot not inoculated as a control. For plants infested with WCM, seedlings were transferred to the growth chamber containing viruliferous mites carrying the disease complex when the third leaf began to emerge from the whorl. To facilitate mite movement and virus transmission, pots of wheat and maize were positioned to have pots of maize plants adjacent to at least one pot of mite-infested wheat. After 4 to $5 \mathrm{~d}$ in the growth chamber, plants were sprayed with miticide (Diamachlor-Sandoz, Des Plaines, IL) and transferred to the greenhouse for subsequent grow-out and disease symptom rating. This technique has provided a very uniform and reproducible inoculation challenge within and between experiments when screening maize inbred genotypes for HPV resistance (Marçon et al., 1997a; Marçon et al., 1998). For the finger-thumb rub inoculation, plants were sprayed with carburundum and hand inoculated with WSMV, in a dilution of 1:5 (w/v) at the same stage of development as those in the mite-infested experiment. The growth chamber day and night temperature for the experiment was maintained at $27^{\circ} \mathrm{C}$ and $\approx 70 \%$ humidity, with $350 \mathrm{mmol}$ $\mathrm{m}^{-2} \mathrm{~s}^{-1}$ of light (14:10 $\mathrm{h}$ light/dark). The greenhouse day/night temperature for the experiment was maintained at $\approx 27$ and $21^{\circ} \mathrm{C}$, respectively.

\section{Disease Scoring and Virus Assay}

Symptom ratings started 3 to 4 wk after plants were miteinoculated with HPV-TX and WSMV-AM. The rating scale for infected plants was based on the following criteria. For localized symptom rating for doubly infected plants a 1 to 4 scale system was used, where 1 is no spots observed, 2 is few visible chlorotic spots, 3 is chlorotic spots coalescing with whole areas showing chlorotic lesions, and 4 is necrosis advancing and leaf death. These ratings were taken on the lower four to five leaves. For systemic symptom rating for doubly infected plants and plants infected with WSMV alone, a 1 to 3 scale system was used, where 1 is no visual spread of virus, 2 is medium spread, and 3 is rapid spread. Rate of systemic spread was determined by the amount of symptoms on upper, newly emerging leaves that had not been rub-inoculated. Leaves rated for systemic symptom development in doubly infected plants were the eighth or above and should not have been available for mite feeding.

Disease symptoms were scored on an individual plant basis and averaged within pots. The uppermost leaf of the five plants in a pot were pooled and sampled for double antibody sandwich-enzyme-linked immunosorbent assay (DAS-ELISA) (Clark and Adams, 1977) when the tassel began to emerge. The DAS-ELISA procedure was the same as that used in previously reported experiments (Marcon et al., 1997, 1998). In brief, DAS-ELISA was used to verify HPV-TX and WSMV-AM infections in all experiments. The leaves were placed in a $2-\mathrm{mL}$ plastic sleeve, and the sap was expressed in a roller press. The sap was diluted 1:4 (v/v) for WSMV and $1: 10(\mathrm{v} / \mathrm{v})$ for HPV before loading onto ELISA plates. Specific antibody generated against the 32 kilodaltons $(\mathrm{kDa})$ HPVassociated protein and antibody specific against the $44 \mathrm{kDa}$ WSMV protein was used in all experiments. Known negative and positive controls were included in each assay, to ensure representation of known values. Each sample of sap was included twice in an ELISA experiment and values averaged.

The WSMV ELISA titer from hand-inoculated plants will be referred to as WSMV $(\mathrm{H})$ titer, WSMV ELISA titer from 
mite-inoculated (doubly infected) plants will be referred to as WSMV(M) titer, and HPV ELISA titer from mite inoculated (doubly infected) plants will be referred to as HPV(M) titer. Rating scores will be labeled as follows. Systemic wheat streak mosaic ratings on hand-inoculated plants will be referred to as WSM $(\mathrm{H})$ rating. Systemic ratings on mite-inoculated plants (doubly infected with the disease complex of HPV and WSMV) will be referred to as Systemic(M) rating. Localized rating on mite-inoculated plants (doubly infected with the disease complex of HPV and WSMV will be referred to as Localized(M) rating.

\section{Statistical Analysis}

Correlations among symptom ratings and ELISA values were computed and tested for significance (SAS Institute, 1988). Raw and transformed phenotypic data (symptom ratings and ELISA values) were tested for deviations from normality using a W statistic analysis (Shapiro and Wilk, 1965).

Marker data was provided by C. Stuber (North Carolina State University) and W. Beavis (Pioneer Hi-Bred Intl., Inc.). A total of 167 markers were available on the population of 129 lines from North Carolina State (NCS-RI), and 214 markers available on the population from Pioneer Hi-Bred Intl. (PIORI). Since many markers were not in common between the two populations, the North Carolina State University population was used to build a QTL model and the Pioneer Hi-Bred population was used to validate the model. In the NCS-RI population, 27 markers were tested on chromosome 1,14 on chromosome 2, 16 on chromosome 3,23 on chromosome 4 , 17 on chromosome 5,10 on chromosome 6,13 on chromosome 7, 17 on chromosomes 8,18 on chromosome 9 , and 12 on chromosome 10 . In the PIO-RI population, for the verification analysis a single marker was chosen based on its proximity to QTL identified in the North Carolina State University population. The relative position of the markers in the first and second populations was determined from information in the Maize DB (Maize Genome Database, http://teosinte.agron. missouri.edu/).

Single-factor analysis of variance (ANOVA) was performed for each marker with each trait. $F$ tests were used to determine marker significance. Marker loci significantly associated with trait variation by single-factor ANOVA $(P<$ $0.05)$ and all possible marker $\times$ loci interactions were entered into a multiple regression analysis. Since three regions or less were significant, it was possible to include all two-way and three-way interactions in the multiple model. Only the most significant marker in linked groups of significant markers was used in the multiple regression model. Significance of markers and interactions in the multiple model was determined using Type III sums of squares (Knapp et al., 1992). Nonsignificant markers or interactions $(P>0.05)$ were removed after the first multiple factor analysis, and total model $R^{2}$ determined from the final model containing only significant effects. The additive effect of each locus was calculated using least square means according to Falconer (1981). Epistatic interactions were assessed using two- and three-way tables of marker means.

\section{RESULTS}

\section{Summary of Symptom Expression}

Thirty-three of 129 lines hand inoculated with WSMV showed clearly visible systemic symptoms. B73 showed no WSMV systemic symptoms and Mo17 showed few WSMV systemic symptoms in hand-inoculated plants.
Therefore, segregation was transgressive for susceptibility in the population. All susceptible plants did not show the same rate of symptom development so data were taken as ratings [WSM $(\mathrm{H})$ rating] rather than scored as presence or absence of symptoms. In addition, ELISA values [WSM $(\mathrm{H})$ titer] were continuous, with no obvious categorical divisions (data not shown). Therefore, the trait and marker associations were analyzed using a quantitative rather than categorical approach.

Sixty-seven of 129 lines doubly infected with WSMV and HPV by mite inoculation showed visible systemic symptoms. Symptoms in doubly infected susceptible lines were much more severe than the same genotypes inoculated with WSMV alone. Doubly infected susceptible plants were severely stunted and had obvious symptoms; susceptible plants inoculated with WSMV alone were nearly as vigorous as the noninoculated controls and had much more subtle symptom expression. B73 had no visible symptoms when doubly infected, and Mo17 had only mild symptoms. Therefore, transgressive segregation for susceptibility was also observed in doubly infected plants. Ratings were taken on doubly infected plants to quantify variability observed among susceptible lines. Lower leaves available for WCM feeding [Localized(M) rating] and upper leaves not available for WCM feeding [Systemic(M) rating] were scored based on symptom expression. The HPV(M) titer and WSMV(M) titer did not show obvious breaks in the distribution so, as with WSMV hand-inoculated plants, trait marker associations were analyzed using a quantitative rather than categorical approach.

The WSM $(\mathrm{H})$ rating and WSMV $(\mathrm{H})$ titer were significantly correlated $\left(r^{2}=0.66\right)$ in hand-inoculated plants. The WSM(H) rating and $\operatorname{WSMV}(\mathrm{H})$ titer were also significantly correlated with WSMV(M) titer and less, but significantly, correlated with Systemic(M) rating. Systemic $(M)$ rating and $\operatorname{HPV}(\mathrm{M})$ titer had the highest correlation $\left(r^{2}=0.69\right)$ (Table 1). Localized(M) rating was correlated with Systemic(M) rating and HPV(M) titer, but not with any phenotype involving WSMV alone. These correlations indicate the following. First, based on WSMV titer, recombinant inbred lines responded similarly when inoculated with WSMV by hand or when doubly infected. Second, the correlations indicate that at least some genes controlling HPV titer and WSMV titer are linked or pleiotropic. This correlation also existed in our screening of unrelated inbred lines (Marcon et al., 1997a) and in our genetic analysis of B73 $\times$ W64A and B73 $\times$ Wf9 (Marcon et al., 1997b). Third, Systemic $(M)$ rating was correlated more with HPV(M) titer $\left(r^{2}=0.69\right)$ than with WSMV(M) titer $\left(r^{2}=0.36\right)$ in doubly infected plants. This is consistent with the observation that the phenotype of doubly infected plants is much more severe than plants infected with WSMV alone.

\section{Wheat Streak Mosaic Resistance Maps to Chromosomes 3, 6, and 10}

Single-factor ANOVA identified three chromosome regions significantly $(P<0.05)$ associated with 
Table 1. Disease symptom development and virus titer correlations for resistance to High Plains disease complex and wheat streak mosaic (WSM) among $129 \mathrm{B73} \times$ Mo17 recombinant inbred lines, based on hand inoculation (H) of wheat streak mosaic virus (WSMV), and mite infestation (M) carrying WSMV and High Plains virus (HPV).

\begin{tabular}{|c|c|c|c|c|c|}
\hline Trait & $\underset{\text { titer }}{\text { WSMV(H) }}$ & $\begin{array}{c}\text { WSMV(M) } \\
\text { titer }\end{array}$ & $\begin{array}{l}\text { Systemic(M) } \\
\text { rating }\end{array}$ & $\underset{\text { titer }}{\operatorname{HPV}(M)}$ & $\begin{array}{l}\text { Localized(M) } \\
\text { rating }\end{array}$ \\
\hline $\begin{array}{l}\text { WSM(H) rating } \\
\text { WSMV(H) titer } \\
\text { WSMV(M) titer } \\
\text { Systemic(M) rating } \\
\text { HPV(M) titre }\end{array}$ & $0.66^{* *}$ & $\begin{array}{l}0.60 * * \\
0.63^{* *}\end{array}$ & $\begin{array}{l}0.56^{* *} \\
0.45^{* *} \\
0.36^{*}\end{array}$ & $\begin{array}{l}0.54^{* *} \\
0.59^{* *} \\
0.54^{* *} \\
0.69^{* *}\end{array}$ & $\begin{array}{l}0.22 \\
0.17 \\
0.00 \\
0.48 * * \\
0.43^{* *}\end{array}$ \\
\hline
\end{tabular}

*,** Significant at the 0.01 and 0.001 levels of probability, respectively.

WSM(H) rating, WSMV $(\mathrm{H})$ titer on chromosome 3 (asg 48), chromosome 6 (umc85), and on chromosome 10 (phi062) (Table 2). These regions were also significant for WSMV(M) except for the region marked by umc85, which had a $P$-value of 0.09 . Based on estimates of additive effects, chromosome 10 had the largest effect on all three WSMV-related traits. The map positions of asg 48, umc85, and phi062 are consistent with the location of $w s m 2$, wsm1, and wsm3, respectively (McMullen and Louie, 1991; McMullen et al., 1994).

A significant $(P<0.05)$ interaction was detected among markers asg48 and phi062 on chromosomes 3 and 10 , respectively, for $\operatorname{WSM}(\mathrm{H})$ rating, $\operatorname{WSMV}(\mathrm{H})$ titer, and WSMV(M) titer (Table 2). A significant interaction was also detected among markers umc85 and phi062 on chromosomes 6 and 10, respectively, for WSMV(H) titer. McMullen et al. (1994) have reported that the allelic status at wsm 3 in plants homozygous susceptible at wsm 1 and wsm 2 determines whether plants develop dispersed chlorotic rings and spots or generalized mosaic. We did not observe this clear phenotypic distinction. The epistasis detected in this population mostly reflected the amount of symptom expression and the virus titer. On average, plants with susceptibility alleles on chromosomes 3 (B73 allele at asg 48), 6 (Mo17 allele at $u m c 85$ ), and 10 (B73 allele at phi062) showed clear symptom development and high virus titer. On the basis of symptoms and virus titer, all other classes showed partial to total resistance (Table 3 ).

Based on WSMV $(\mathrm{H})$ rating and WSMV $(\mathrm{H})$ titer, mean comparisons among the four genotypes involving allelic-pairs at the chromosome 3 and 10 QTL indicated a complementary epistasis model (Table 3 ). Genotypes with both susceptible alleles showed the highest disease score (1.75) and highest virus titer (1.07), compared with the presence of either or both resistant alleles, which showed similar, resistant results.

\section{Resistance to High Plains Disease Maps to Chromosomes 3 and 6}

On the basis of Systemic(M) rating and HPV(M) titer in doubly infected plants, marker loci asg 48 on chromosome 3 and $u m c 85$ on chromosome 6 showed significant associations with resistance to High Plains disease. Marker umc85 on chromosome 6 was the only significant marker for HPV(M) titer, but the interaction between asg48 and umc85 was significant for this trait, indicating the importance of the chromosome 3 region for both phenotypes. Chromosome 6 had the largest additive effect for both traits (Table 4) with the resistance allele contributed by $\mathrm{B} 73$. The resistance allele on chromosome 3 was contributed by Mo17. The twolocus model with the interaction accounted for 41 and $38 \%$ of the phenotypic variation for Systemic(M) rating and HPV(M) titer, reflecting the large effect of these chromosome regions. While chromosome 10 , near $w s m 3$, was not significant for either Systemic(M) rating or $\operatorname{HPV}(\mathrm{M})$ titer in this analysis, the genotypic means do not completely rule out a potential effect of this region on resistance to the HPV-WSMV complex. The mean for the Mo17 genotype at phi062 for both Systemic(M) rating and HPV(M) titer was toward a more susceptible phenotype [Systemic (M) rating: Mo17 = $1.42 \pm 0.54, \mathrm{~B} 73=1.28 \pm 0.40 ; \mathrm{HPV}(\mathrm{M})$ titer: $\mathrm{Mo17}$ $=0.70 \pm 0.35, \mathrm{~B} 73=0.43 \pm 0.21]$. A larger population size or improved experimental precision may allow an effect on resistance to the HPV-WSMV complex to be defined for this region.

Means for Systemic(M) rating and HPV(M) titer were calculated based on the combined marker genotypes of asg48 and umc85 (Table 5). Genotypes with both susceptible alleles (from B73 on chromosome 3 and from Mo17 on chromosome 6) showed the highest Systemic(M) rating (1.70) and HPV(M) titer $(0.76)$. The other classes were not significantly different from one

Table 2. Significance and effect of single locus and locus interactions associated with wheat streak mosaic (WSM) disease resistance in 129 B73 $\times$ Mo17 recombinant inbred lines based on symptom ratings on hand inoculated plants, and ELISA analysis of hand (H)and mite (M)-inoculated plants.

\begin{tabular}{|c|c|c|c|c|c|c|c|}
\hline \multirow[b]{2}{*}{ Loci } & \multirow[b]{2}{*}{ Chromosome } & \multicolumn{2}{|c|}{ WSM(H) rating } & \multicolumn{2}{|c|}{ WSMV(H) titer } & \multicolumn{2}{|c|}{ WSMV(M) titer } \\
\hline & & $\boldsymbol{P}>\boldsymbol{F}$ & Additive effect $\dagger$ & $P>F$ & Additive effect & $\boldsymbol{P}>\boldsymbol{F}$ & Additive effect \\
\hline $\begin{array}{l}\text { asg48 } \\
\text { umc85 } \\
\text { phi062 } \\
\text { asg48 } \times \text { phi062 } \\
\text { umc85 } \times \text { phiO62 } \\
\text { Total model } R^{2} \ddagger\end{array}$ & $\begin{array}{l}3 \\
6 \\
10 \\
3 \times 10 \\
6 \times 10\end{array}$ & $\begin{array}{c}0.002 \\
0.000 \\
0.000 \\
0.004 \\
\text { ns }\end{array}$ & $\begin{array}{l}+0.16 \\
-0.18 \\
+0.20\end{array}$ & $\begin{array}{l}0.002 \\
0.017 \\
0.004 \\
0.004 \\
0.016\end{array}$ & $\begin{array}{r}+0.18 \\
-\mathbf{0 . 1 4} \\
+\mathbf{0 . 3 1}\end{array}$ & $\begin{array}{c}\mathbf{0 . 0 0 3} \\
\text { ns } \\
0.007 \\
0.007 \\
\text { ns }\end{array}$ & $\begin{array}{r}+0.17 \\
-0.16 \\
+0.29\end{array}$ \\
\hline
\end{tabular}

† Calculated as the (mean of the homozygous B73 genotype - mean of the homozygous Mo17 genotype)/2. A lower resistance rating is more favorable so negative effects indicate $B 73$ carries a resistance allele and positive effects indicate Mo17 contributes the resistance allele.

¥ Variance explained by the combined model of significant loci and interactions. 
Table 3. Quantitative trait loci interaction effects of chromosome regions affecting wheat streak mosaic (WSM) resistance. Values indicate the mean of all recombinant inbred lines with each of the two-locus genotype classes. $\dagger$

\begin{tabular}{|c|c|c|c|}
\hline & \multicolumn{2}{|c|}{ Locus asg48 (3) genotype } & \multirow[b]{2}{*}{ Difference } \\
\hline & B73 & Mo17 & \\
\hline \multicolumn{4}{|l|}{ WSMV (M) titer } \\
\hline $\begin{array}{l}\text { Locus phi062 (10) genotype } \\
\text { B73§ } \\
\text { Mo17 } \\
\text { Difference }\end{array}$ & $\begin{array}{r}\text { WSMV } \\
\text { arbitrary } \\
\mathbf{1 . 1 0} \\
\mathbf{0 . 3 4} \\
\mathbf{0 . 7 6}\end{array}$ & $\begin{array}{l}\text { er mean } \\
\text { ince units } \\
0.30 \\
\mathbf{0 . 3 0} \\
\mathbf{0 . 0 0}\end{array}$ & $\begin{array}{l}0.80 \\
0.04\end{array}$ \\
\hline \multicolumn{4}{|l|}{ WSMV (H) titer } \\
\hline $\begin{array}{l}\text { Locus phi062 (10) genotype } \\
\text { B73 } \\
\text { Mo17 } \\
\text { Difference }\end{array}$ & $\begin{array}{r}\text { WSMV } \\
\text { arbitrary } \\
\mathbf{1 . 0 7} \\
\mathbf{0 . 2 5} \\
\mathbf{0 . 8 2}\end{array}$ & $\begin{array}{l}\text { er mean } \\
\text { nce units } \\
0.22 \\
0.22 \\
0.00\end{array}$ & $\begin{array}{l}0.85 \\
0.03\end{array}$ \\
\hline \multicolumn{4}{|l|}{ WSM (H) rating } \\
\hline $\begin{array}{l}\text { Locus phi062 (10) genotype } \\
\text { B73 } \\
\text { Mo17 } \\
\text { Difference }\end{array}$ & $\begin{array}{c}\text { WSM (H) } \\
\text { arbitra } \\
1.75 \\
1.14 \\
\mathbf{0 . 6 1}\end{array}$ & $\begin{array}{l}\text { gocre mean } \\
\text { g units } \\
1.11 \\
1.10 \\
0.01\end{array}$ & $\begin{array}{l}0.64 \\
0.04\end{array}$ \\
\hline
\end{tabular}

$\mp(\mathrm{MO})$ is mite inoculated, $(\mathrm{H})$ is hand inoculated.

$¥$ Chromosome number in parentheses.

$\$$ Allele designation; B73 indicates lines homozygous for the B73 marker allele, and Mo17 indicates lines homozygous for the Mol7 marker allele. Heterozygous were infrequent and not included in the calculation of means.

another, indicating a complementary epistatic interaction among the two loci.

\section{Localized Symptom Development Controlled by Loci on Chromosomes 4, 5, and 6}

Regions on chromosomes 4 (umc66), 5 (bnl5.40), and 6 (umc85) were significantly $(P<0.01)$ associated with Localized(M) ratings. No significant interactions involving marker loci were identified (Table 6). The QTL model containing the three markers accounted for 24 $\%$ of the phenotypic variation for the trait and all three markers were relatively equal in effect. The significant marker $u m c 85$ associated with both Localized(M) rating and Systemic(M) rating provided an explanation for the correlation between the two traits. Resistant alleles were contributed by B73 on chromosomes 5 and 6 , and by Mo17 on chromosome 4. This is consistent with the observation that B73 has less localized symptom development than Mo17.

\section{Verification of the QTL Model with a Second B73 $\times$ Mo17 Recombinant Inbred Population}

The availability of a second, independently derived B73 $\times$ Mo17 recombinant inbred population allowed us to verify our QTL model. While many markers were not in common in the two populations, the density of markers across the genome allowed us to select markers linked to those found in the first study (position based on MaizeDB) for the verification procedure. To verify our first analysis, the best models for each trait were tested for significance on the second data set, and the predicted vs. actual phenotypes compared by correlation. Marker bn15.37 on chromosome 3, bnl6.29 on chromosome 6 , and $u m c 57$ on chromosome 10 were used in the verification analysis. Marker bnl6.29 on chromosome 6 was found to be completely linked to Systemic(M) score in our previous analysis of B73 $\times$ W64A and B73 $\times$ Wf9 populations (Marcon et al., 1997).

Using markers and interactions identified in the first analysis as variables (Tables 2 and 4 ), all models tested were confirmed to be signficant $(P>0.01)$ in the Pioneer population. The models account for $45,65,47$, and $35 \%$ of the phenotypic variation for $\operatorname{WSMV}(\mathrm{H})$ titer, Systemic(M) rating, WSMV(M) titer, and HPV(M) titer, respectively. The WSMV $(\mathrm{H})$ rating and Localized(M) rating were not taken on the Pioneer population. Weighted models were then used to generate predicted phenotypic values for the Pioneer population of 45 lines. Correlations between predicted and observed phenotypic values for the 45 lines were 0.59 for WSMV(H) titer, 0.73 for Systemic(M) rating, 0.65 for WSMV(M) titer, and 0.59 for HPV(M) titer. All correlations were highly significant $(P<0.001)$. The significance of the models across traits and the highly significant correlations between predicted and observed phenotypes support the validity of the predicted model and the potential utility of marker-assisted selection. The significance of the predicted models across populations is encouraging considering the small population size used for validation; the fact that markers used in the validation were linked, but not identical to, the markers used in the calibration experiment; and the inherent variability in the ELISA procedure.

\section{DISCUSSION}

It has been difficult to study resistance to HPV in maize since obligate mite transmission increases the difficulty of plant inoculation and of separating HPV and WSMV. The two pathogens often occur as a mixed infection in the field, and there is no mechanical inoculation method that will transmit HPV but not WSMV, making it difficult to isolate pure cultures of HPV. Due to these difficulties, which may be unique to this pair of pathogens, we have proceeded in our analyses using plants doubly infected with HPV and WSMV. This study shows that this method is appropriate for the study of HPV resistance especially when coupled with ELISA

Table 4. Loci associated with Systemic $(M) \dagger$ rating resistance, and virus titer in $129 \mathrm{B73} \times$ Mo17 recombinant inbred lines, detected by multiple regression of molecular marker and phenotypic data.

\begin{tabular}{|c|c|c|c|c|c|}
\hline \multirow[b]{2}{*}{ Loci } & \multirow[b]{2}{*}{ Chromosome } & \multicolumn{2}{|c|}{ Systemic(M) rating } & \multicolumn{2}{|c|}{ HPV(M) titer } \\
\hline & & $P>F$ & Additive effect & $P>F$ & Additive effect \\
\hline $\begin{array}{l}\text { asg48 } \\
\text { umc85 } \\
\text { asg } 48 \times \text { umc85 } \\
\text { Total model } R^{2}\end{array}$ & $\begin{array}{l}3 \\
6 \\
3 \times 6\end{array}$ & $\begin{array}{l}0.016 \\
0.000 \\
0.094\end{array}$ & $\begin{array}{r}0.13 \\
-0.26\end{array}$ & $\begin{array}{l}0.076 \\
0.000 \\
0.019\end{array}$ & $\begin{array}{r}0.10 \\
-\mathbf{- 0 . 1 4}\end{array}$ \\
\hline
\end{tabular}

$\dagger(M)$ is mite inoculated. 
Table 5. Quantitative trait loci interaction effects based on means of Systemic(M) ratings and HPV(M) titer. Values indicate the mean of all recombinant inbred lines with each of the twolocus genotype classes. $\dagger$

\begin{tabular}{|c|c|c|c|}
\hline & \multicolumn{2}{|c|}{ Locus asg48 (3) genotype } & \multirow[b]{2}{*}{ Difference } \\
\hline & $\mathbf{B 7 3}$ & Mol7 & \\
\hline \multicolumn{4}{|l|}{ Systemic(M) rating } \\
\hline $\begin{array}{l}\text { Locus umc85 (6) genotype } \neq \\
\text { B73\$ } \\
\text { Mo17 } \\
\text { Difference }\end{array}$ & $\begin{array}{r}\text { Systemic } \\
\text { arbitr: } \\
1.09 \\
1.70 \\
0.61\end{array}$ & $\begin{array}{l}\text { ng mean } \\
\text { units } \\
1.04 \\
1.36 \\
0.32\end{array}$ & $\begin{array}{l}0.05 \\
\mathbf{0 . 3 4}\end{array}$ \\
\hline \multicolumn{4}{|l|}{ HPV(M) titer } \\
\hline $\begin{array}{l}\text { Locus umc85 (6) genotype } \\
\text { B73 } \\
\text { Mo17 } \\
\text { Difference }\end{array}$ & $\begin{array}{c}\text { HPV } \\
\text { arbitrary } \\
\mathbf{0 . 3 5} \\
\mathbf{0 . 7 6} \\
\mathbf{0 . 4 1}\end{array}$ & $\begin{array}{l}\text { mean } \\
\text { nce units } \\
0.38 \\
0.31 \\
0.07\end{array}$ & $\begin{array}{l}0.03 \\
0.45\end{array}$ \\
\hline
\end{tabular}

$\dagger(M)$ is mite inoculated.

† Chromosome number under marker loci.

\$ Allele designation; B73 indicates lines homozygous for the B73 marker allele, and Mol7 indicates lines homozygous for the Mol7 marker allele. Heterozygous were infrequent and not included in the calculation of means.

and with hand inoculation of WSMV alone on the same genotypes. Using analysis of doubly infected plants coupled with the same genotypes inoculated with WSMV we have identified lines susceptible to HPV but resistant to WSMV. A caveat of this research approach is that QTL for resistance to HPV may be specific to infection of the HPV/WSMV disease complex. Inoculation with pure HPV by a method which correlates with field disease development is a necessary future research objective to unambiguously determine the effect of these genes on resistance to HPV alone.

In this study, chromosome $6 \mathrm{~S}$ has been found to be important for both HPV and WSMV resistance having a major effect on HPV resistance in this population. This corroborates our mapping results in the $B 73 \times$ W64A and B73 $\times$ Wf9 populations, in which the chromosome $6 \mathrm{~S}$ region was the major region segregating for resistance to the two pathogens (Marcon et al., 1998). This region of chromosome 6 has been shown to be important for resistance to WSMV, MDMV, and Cochliobolus heterostrophus (Drechs.) Drechs. Recombinants in the umc85-phi077 interval have been identified in this population which are very susceptible to HPV but resistant to WSMV, with resistance to WSMV confirmed by hand inoculation. Unambiguous interpretation of these results is complicated by segregation of other loci segregating for WSMV resistance, so further genetic analysis is required to determine whether these

Table 6. Loci associated with Localized(M) rating resistance in 129 B $73 \times$ Mo17 recombinant inbred lines, detected by multiple regression of molecular marker and phenotypic data. $\dagger$

\begin{tabular}{lccc} 
& & \multicolumn{2}{c}{ Localized(M) rating } \\
\cline { 3 - 4 } Loci & Chromosome & $P>F$ & Additive effect \\
\hline umc66 & 4 & 0.004 & 0.13 \\
bul5.40 & 5 & 0.004 & -0.16 \\
umc85 & 6 & 0.004 & -0.14 \\
Total model $R^{2}$ & & & 24 \\
\hline
\end{tabular}

$\dagger(M)$ is mite inoculated. recombination events have separated resistance factors on $6 \mathrm{~S}$; however, this study shows that doubly infected genotypes showing systemic spread of HPV and WSMV, or only WSMV, can be derived from a cross of two parents that are resistant (B73) and moderately resistant (Mo17).

This study has several important implications in breeding for virus resistance. First, the presence of multiple epistatic factors for resistance shows that it is possible to derive highly susceptible inbred lines from a cross of two parents with moderate to high resistance. This was observed in our study, with 37 of 129 progeny being much more susceptible than either parent. Second, the cosegregation of resistance factors on chromosomes 3 and 6 adds HPV to the number of pathogens affected by these chromosome regions. This clustering of resistance genes is important in parent selection because if a chosen parent is resistant to one pathogen but susceptible to another in the cluster, selection for resistance to the first pathogen will almost guarantee susceptibility to the other in the progeny. Finally, epistatic interactions among resistance loci will negate the possibility of phenotypically selecting plants with multiple resistance factors without tedious testcrossing. On the basis of our studies to date, a combination of resistance factors on chromosomes 3,6 , and 10 provides the highest level of protection against WSMV and HPV. Molecular markers can be used to efficiently pyramid these genes during line development, with the possibility of increasing the long-term stability of resistance.

The location of genes for resistance to WSMV in this study is not new information, but does confirm that these loci are segregating in a population unrelated to Pa405 and Oh28 (McMullen and Louie, 1991; McMullen et al., 1994). In addition, our data show that these loci have the same effect whether WSMV is transmitted by hand or by mites, and that they control WSMV resistance in the presence of a second pathogen, HPV.

Since HPV infection seems most devastating on fieldgrown plants infected as seedlings (Jensen, 1994, unpublished data), we are currently suggesting that resistance to systemic virus spread is the trait of most practical importance. However, if infection of older plants can also detrimentally affect traits such as yield, resistance to localized symptom development may also become an important trait. This study provides the first report of chromosome regions controlling resistance to localized symptom development in doubly infected plants. The chromosome $6 \mathrm{~S}$ region affects both systemic and localized symptoms, whereas the loci on 4 and 5 did not significantly affect systemic symptom development. Resistance in the chromosome 4 and 5 regions could involve resistance to mite feeding, resistance to virus replication, or resistance to localized virus movement. This trait is very difficult to study in the field, because it is difficult to know which leaves have been available for mite feeding, with the probability that all leaves experience mite feeding throughout the season. Further analysis will determine if loci affecting localized symptoms confer insect feeding resistance (e.g., by antixenosis) or affect virus replication or spread. 
This study shows that regions on chromosomes 3 and 6 are of major importance for HPV resistance, and regions on 3,6 , and 10 are of major importance for WSMV resistance in this population. Information on environmental factors affecting these resistance genes, and genetic variability among virus and mite strains still needs to be gathered in order for us to fully understand the stability of the resistance phenotype across locations. We believe that the information here is of practical importance to breeders, even though we did not analyze these populations with HPV in the absence of WSMV. Most plants in the field will be challenged with a mixed infection of the pathogens, supporting the relevance of our results. Resistance to both HPV and WSMV is controlled by a small number of major factors, indicating resistance should be highly heritable. Incorporation of molecular markers into breeding programs will allow pyramiding of resistance factors and should enhance selection efficiency.

\section{ACKNOWLEDGMENTS}

Special thanks to Dr. William Beavis at Pioneer Hi-Bred for providing seed and marker information. Thank you also to Jeffrey Hall for assistance with ELISA analysis.

\section{REFERENCES}

Ahn, K.K., S.G. Jensen, E.J. Anderson, R.C. Gergerich, and K.S. Kim. 1995. A viruslike disease of corn and wheat in the High Plains: Ultrastructural aspects. Phytopathology 85:1183.

Ahn, K.K., K.S. Kim, R.C. Gergerich, S.G. Jensen, and E.J. Anderson. 1996. Comparative ultrastructure of double membrane-bound particles and inclusions associated with eriophyid mite-born plant diseases of unknown etiology: A potentially new group of plant viruses. J. Submicrosc. Cytol. Pathol. 28:345-355.

Brakke, M.K. 1971. Wheat streak mosaic virus. CMI/AAB Descriptions of Plant Viruses, no. 48. Farnham Royal, Slough, England.

Clark, M.F., and A.M. Adams. 1977. Characteristics of the microplate method of enzyme-linked immunosorbent assay for the detection of plant viruses. J. Gen. Virol. 34:475-483.

Doebley, J., A. Stec, J. Wendel, and M. Edwards. 1990. Genetic and morphological analysis of a maize-teosinte $F_{2}$ population: Implications for the origin of maize. Proc. Natl. Acad. Sci. USA 87: 9888-9892

Falconer, D.S. 1981. Introduction to quantitative genetics. Wiley, New York.

Findley, W.R., R. Louie, J.K. Knoke, and E.J. Dollinger. 1974. Breeding corn for resistance to virus in Ohio. p. 123-127. In L.E. Williams et al. (ed.) Proc. Intl. Maize Virus Dis. Colloq. and Workshop, Ohio Agric. Res. Dev. Cent., Wooster.

Findley, W.R., R. Louie, and J.K. Knoke. 1984. Breeding corn for resistance to corn viruses in Ohio. Proc. 39th Annual Corn and Sorghum Ind. Res. Conf. 39:52-67.

Goldberg, K.B., and M. Brakke. 1987. Concentration of maize chlorotic mottle virus increased in mixed infections with maize dwarf mosaic virus, strain B. Phytopathology 77:162-167.

Jardine, D.J., R.L. Bowden, and S.G. Jensen. 1994. A new virus of corn and wheat in western Kansas. Phytopathology 84:1117-1118.

Jensen, S.G., and L.C. Lane. 1994. A new virus disease of corn and wheat in the High Plains. Phytopathology 84:1158.

Jensen, S.G. 1994. The High Plains virus - A new threat to corn and wheat production in the West. Proc. In D.B. Wilkinson (ed.) 49th Annual Corn and Sorghum Ind. Res. Conference. 7-8 Dec. 1994.

Jensen, S.G., L.C. Lane, and D.L. Seifers. 1996. A new disease of maize and wheat in the High Plains. Plant Dis. 80:1387-1390.
Jung, G., P.W. Skroch, D.P. Coyne, J. Nienhuis, E. Arnaud-Santana, S.M. Kaeppler, and M.J. Basset. 1997. Molecular-marker-based genetic analysis of tepary bean-derived common bacterial blight resistance in different developmental stages of common bean. J. Am. Soc. Hortic. Sci. 122:329-337.

Kyle, M., M.H. Dickinson, R. Providenti, and H.M. Munger. 1986. A major gene for broad-spectrum virus resistance in Phaseolus vulgaris L. HortScience 21:1557.

Marçon, A., S.M. Kaeppler, and S.G. Jensen. 1996. Molecular markers linked to genes conferring resistance to high plains virus (HPV) in maize. p. 164. In 1996 Agronomy abstracts. ASA, Madison, WI.

Marçon, A., S.M. Kaeppler, and S.G. Jensen. 1997a. Genetic variability among maize inbred lines for resistance to the High Plains virus/ wheat streak mosaic virus complex. Plant Dis. 81:195-197.

Marçon, A., S.M. Kaeppler, and S.G. Jensen. 1997b. Resistance to systemic spread of High Plains virus and wheat streak mosaic virus cosegregates in two $F_{2}$ maize populations inoculated with both pathogens. Crop Sci. 37:1923-1927.

McKinney, H.H. 1949. Virus isolates from mosaic wheat in the hard red winter area. Plant Dis. Rep. 33:346-349.

McMullen, M.D., M.W. Jones, K.D. Simcox, and R. Louie. 1994 Three genetic loci control resistance to wheat streak mosaic virus in the inbred Pa405. Mol. Plant-Microbe Interact. 7:708-712.

McMullen, M.D., and R. Louie. 1989. The linkage of molecular markers to a gene controlling the symptom response in maize to maize dwarf mosaic virus. Mol. Plant-Microbe Interact. 2:309-314.

McMullen, M.D., and R. Louie. 1991. Identification of a gene for wheat streak mosaic virus in maize. Phytopathology 81:624-627.

McMullen, M.D., and K.D. Simcox. 1995. Genome organization of disease and insect resistance genes in maize. Mol. Plant-Microbe Interact. 8:811-815.

Nault, L.R., W.E. Styer, D.T. Gordon, O.E. Bradfute, H.N. Lafever, and L.E. Williams. 1970. An eriophyid-borne pathogen from Ohio, and its relation to wheat spot mosaic virus. Plant Dis. Rep. 54 $156-160$.

Niblett, C.L., and L.E. Claflin. 1978. Corn lethal necrosis: a new virus disease of corn in Kansas. Plant Dis. Rep. 62:195-198.

Paterson, A.H., S. Damon, J.D. Hewitt, D. Zamir, H.D. Rabinowitch, S.E. Lincoln, E.S. Lander, and S.D. Tanksley. 1991. Mendelian factors underlying quantitative traits in tomato: comparison across species, generations, and environments. Genetics 127:181-197.

Rodriguez-Ballesteros, O.R., A. Marçon, R.A. Frederiksen, C.M Rush, G. Heidel, D. Jeffers, S.M. Kaeppler, and S.G. Jensen. 1996. Genetics of resistance to High Plains Disease in maize. p. 59-77. In C.M. Rush and G.J. Michels, Jr. (ed.) Proc. High Plains Dis. Symp., Amarillo, TX. 18-25 Oct. 1995.

SAS Institute. 1988. SAS procedures guide. Release 6.03 ed. SAS Inst., Cary, NC.

Seifers, D.L., and T.L. Harvey. 1996. The High Plains pathogen: Vector and some host range information. p. 7-14. In C.M. Rush and G.J. Michels, Jr. (ed.) Proc. High Plains Dis. Symp., Amarillo, TX. 18-25 Oct. 1995.

Senior, M.L., E.C.L. Chin, M. Lee, J.S.C. Smith, and C.W. Stuber. 1996. Simple sequence repeat markers developed from maize sequences found in GENBANK database: Map construction. Crop Sci. 36:1676-1683.

Shapiro, S.S., and M.B. Wilk. 1965. An analysis of variance for normality (complete samples). Biometrika 52:591-611.

Simcox, K.D., M.D. McMullen, and R. Louie. 1995. Co-segregation of maize dwarf mosaic virus resistance gene $\mathrm{mdm} 1$, with the nucleolus organizer region of maize. Theor. Appl. Genet. 90:341-346.

Slykhuis, J.T. 1955. Aceria tulipae Keifer (Acarina: Eriophyidae) in relation to the spread of wheat streak mosaic. Phytopathology $45: 116-128$

Slykhuis, J.T. 1956. Wheat spot mosaic caused by a mite transmitted virus associated with wheat streak mosaic virus. Phytopathology $46: 682-687$

Slykhuis, J.T. 1980. Mites. In K.F. Harris and K. Maramorosch (ed.) Vectors of plant pathogens. Academic Press, New York.

Yu, G.X, A.L. Bush, and R.P. Wise. 1996. Comparative mapping of homocologous group 1 regions and genes for resistance to obligate biotrophs in Avena, Hordeum, and Zea mays. Genome 39:155-164. 